\title{
Relationship between daily activities duration and oestrus in dairy cows over the year
}

\author{
Radim Codl, Jaromír Ducháček, Mojmír Vacek, Jan Pytlík, Luděk Stádník, Marek Vrhel \\ Czech University of Life Sciences Prague, Faculty of Agrobiology, Food and Natural Resources, \\ Department of Animal Science, Prague, Czech Republic
}

Received June 16, 2021

Accepted September 15, 2021

\begin{abstract}
The aim of this study was to evaluate the amounts of time that selected crossbreeds of Holstein (H), Red-Holstein (R), and Czech Fleckvieh (C) cattle spent chewing, eating, being physically active using a Vitalimetr $5 \mathrm{P}$ neck responder during the period around oestrus in all seasons of the year. Oestrus and the days preceding it greatly affected the times of events of increased activity, eating, and rumination. Eating and chewing times were longest for $\mathrm{H}$ cows, at $51-74 \%$, and shortest for $\mathrm{C}$ cows, at $>88 \%$. The number of events of increased activity was highest $(533.4 \pm 8.94$ events, $P<0.01)$ for cows R $51-74 \%$. Oestrus in dairy cows was manifested by decreases in the times of chewing and eating and the frequency of events of increased activity. Feeding time decreased by $8.01 \mathrm{~min}$ from the second day before oestrus to the day of oestrus. Rumination time also decreased from the second day before oestrus to the day of oestrus. Rumination time on the day of oestrus decreased by an average of $61.80 \mathrm{~min}$ but increased the next day by $33.39 \mathrm{~min}$. In contrast, events of increased activity were highest on the day of oestrus ( $623 \pm 7.68$ events $)$. Our findings on differences between breeds, lactation order, and months may contribute to the improvement of algorithms for detecting oestrus, thereby improving the economic status of farms.
\end{abstract}

Oestrus, dairy cattle, chewing, activity, eating

The detection of oestrus is important for the successful management of dairy cattle breeding. Poor reproductive performance is responsible for the highest rates of culling in dairy cows. However, only $10 \%$ of cows culled due to poor reproductive performance were found to have a reproduction system problem, a $90 \%$ majority of them were improperly culled based on oestrus management failure (Diskin and Sreenan 2000).

Breeding costs due to poor oestrus detection, and the associated lack of pregnancy in dairy cows, cause economic losses of up to US\$ 360 for each oestrus missed (De Vries 2006). The activity of dairy cows changes during oestrus, with physical activity increasing at the expense of rumination and feeding times (Reith et al. 2014). Decreases in rumination and feeding times or an increase in physical activity may thus be used to predict oestrus in dairy cows. The success of detecting oestrus in dairy cows improves when two or more physiological indicators are combined for detection (Brehme et al. 2008), and the frequency of errors in detection is reduced, as expected. We used changes in activity to detect the oestrus period using activometers and pedometers, which can detect changes in activity during the oestrous cycle and alert management to the arrival of oestrus. Oestrus detection in dairy cows is more accurate using activometers and pedometers than observation. The accuracy of oestrus detection is only $54-56 \%$ for observation (At-Taras and Spahr 2001) but 79-94\% using activometers (Løvendahl and Chagunda 2010).

The Vitalimetr 5P neck responder can detect changes in dairy cows in chewing, eating, and activity, providing a tool for monitoring oestrus and other indicators to help the management of farms. The use of Vitalimetr 5P, however, has not yet been scientifically validated.

Address for correspondence:

Radim Codl

Department of Animal Science

Faculty of Agrobiology, Food and Natural Resources

Czech University of Life Sciences Prague

Phone +420 224383610

Kamýcká 129, 165 00, Prague - Suchdol, Czech Republic

E-mail: codl@af.czu.cz

http://actavet.vfu.cz/ 
Therefore the aim of this study was to evaluate the amounts of time that selected crossbreeds of Holstein and Czech Fleckvieh cattle spent chewing, eating, being physically active using a Vitalimetr 5P neck responder during the period around oestrus in all seasons of the year.

\section{Materials and Methods}

The experiment was conducted on a farm in the Olomouc region of the Czech Republic at an altitude of about $458 \mathrm{~m}$ a.s.1. The breeding on the farm is focused on milk production in a herd of crossbreeds of Holstein $(\mathrm{H})$, Red Holstein (R), and Czech Fleckvieh cattle (C). The farm had 685 dairy cows at the time of the experiment and averaged $7247 \mathrm{~kg}$ of milk produced in $305 \mathrm{~d}$. The milk had averages of $4.38 \%$ fat and $3.66 \%$ protein. Data were collected during oestrus and two days before and after oestrus for one year (2019). Records from 542 dairy cows with complete records (3352) were selected for evaluation.

The Vitalimetr 5P neck responder (Farmtec a.s., Tisová, Czech Republic) was used to identify the eating time, rumination time, and events of increased activity. Rumination, eating, and increased activity are recognised by accelerometers, and records can be analysed using a detection algorithm. Events of increased activity are recorded when an animal moves at an acceleration $>0.7 \mathrm{~g}$.

The cows were housed in four freestall barns with straw bedding. The cows were milked twice a day in a $2 \times 16$ stall herringbone milking parlour with rapid exits. The cows were fed twice a day using a feed wagon with a strain-gauge scale. The cows were divided into five groups based on the lactation order and stage of lactation. A diet of total mixed feed rations was prepared for each group, and the feed was pushed as needed (5-10 times) each day.

\section{Statistical analysis}

The data were analysed using SAS 9.3 (SAS/STAT ${ }^{\circledR}$ 9.3, 2011). UNIVARIATE and MEANS were used for evaluating basic statistical parameters. REG and STEPWISE were used for selecting factors suitable for use in our model. GLM was used for the evaluation of feeding time, rumination time, activity. The best model was selected based on the Akaike information criterion. Tukey-Kramer post hoc test was used to identify significant differences between least square means. The model used for the evaluation was:

$$
\mathrm{Y}_{\mathrm{i} \mathrm{jk}}=\mu+\text { BREED }_{\mathrm{i}}+\text { LACTATION ORDER }_{\mathrm{j}}+\text { MONTH }_{\mathrm{k}}+\text { OESTRUS }_{1}+\mathrm{b} 1 *(\mathrm{DIM})+\mathrm{b} 2 *(\text { MILK })+\mathrm{e}_{\mathrm{ijkl}}
$$

where $\mathrm{Y}_{\mathrm{ijk} \text { l }}$ is the dependent variable (feeding time, rumination time, events of increased activity), $\mu$ is the mean value of the dependent variable, BREED is the cumulative fixed effect of group $\mathrm{i}$ of a breed $(\mathrm{C} \geq 88 \%, \mathrm{n}=337 ; \mathrm{C} 51-74 \%, \mathrm{n}=1161 ;$ and $\mathrm{C} 75-87 \%, \mathrm{n}=1280 ; \mathrm{H} 51-74, \mathrm{n}=115 ;$ and $\mathrm{R} 51-87, \mathrm{n}=459)$, LACTATION ORDER is the fixed effect of lactation order $\mathrm{j}(1, \mathrm{n}=807 ; 2, \mathrm{n}=946 ; 3, \mathrm{n}=767 ; 4, \mathrm{n}=308$; $\geq 5, \mathrm{n}=452$ ), $\mathrm{MONTH}_{\mathrm{k}}$ is the fixed effect of month $\mathrm{k}$ (January, $\mathrm{n}=310$; February, $\mathrm{n}=285$; March, $\mathrm{n}=390$; April, $\mathrm{n}=360$; May, $\mathrm{n}=305$; June, $\mathrm{n}=272$; July, $\mathrm{n}=256$; August, $\mathrm{n}=276$; September, $\mathrm{n}=236$; October, $\mathrm{n}=220$; November, $\mathrm{n}=211$; December, $\mathrm{n}=231$ ), OESTRUS is the fixed effect of period $\mathrm{k}$ around oestrus ( 2 d before oestrus, $n=849 ; 1$ d before oestrus, $n=859$; day of oestrus, $n=778 ; 1 d$ after oestrus, $n=866$ ), $\mathrm{b} 1 *(\mathrm{DIM})$ is the linear regression of days in milk, b2*(MILK) is linear regression of milk production, and $\mathrm{e}_{\mathrm{ijk}}$ is the random error.

${ }^{\mathrm{ijk}}$ Significant differences between groups were evaluated at $P<0.05, P<0.01$, and $P<0.001$.

\section{Results}

The following average values were determined for the period around oestrus: eating time, $282.27 \mathrm{~min}$; rumination time, $462.94 \mathrm{~min}$; and 495 events of increased activity. For all indicators evaluated, the model was significant $(P<0.001)$ and explained $15.4-22.0 \%$ of the variability. All effects (breed, lactation order, month, days around oestrus, and regression to days of lactation and daily milk) in the model were significant for all times evaluated (eating, rumination, events of increased activity) $(P<0.001)$. Interactions between effects were not evaluated as part of the model because they were inconclusive. The evaluations for eating time, rumination time, and events of increased activity for the effect of breed are presented in Table 1 . The times of eating and chewing during the period around oestrus were significantly $(P<0.01)$ longest for cows $\mathrm{H} 51-74 \%$. In contrast, the times of eating, chewing, and other activities were shortest for cows $\mathrm{C}>88 \%$. The number of events of increased activity was highest (533.4 \pm 8.94 events, $P<0.01)$ for cows R 51-74. 
Table 1. Evaluation for the breed effect $(\mathrm{LSM} \pm \mathrm{SELSM})$.

\begin{tabular}{lccc}
\hline Group of breed & $\begin{array}{c}\text { Feeding time } \\
(\mathrm{min} / \text { day })\end{array}$ & $\begin{array}{c}\text { Rumination time } \\
(\mathrm{min} / \text { day })\end{array}$ & $\begin{array}{c}\text { Number of incresed activity events } \\
(\text { events/day) }\end{array}$ \\
\hline $1 \mathrm{C} \geq 88 \% \quad(\mathrm{n}=337)$ & $261.57 \pm 3.53^{\mathrm{A}, \mathrm{a}}$ & $454.08 \pm 3.79^{\mathrm{A}, \mathrm{a}}$ & $467.40 \pm 10.62^{\mathrm{A}}$ \\
$2 \mathrm{C} 51-74 \%(\mathrm{n}=1161)$ & $273.21 \pm 1.89^{\mathrm{A}, \mathrm{b}}$ & $466.72 \pm 2.03^{\mathrm{C}, \mathrm{b}}$ & $478.20 \pm 5.70^{\mathrm{A}}$ \\
3 C 75 - 87\% $(\mathrm{n}=1280)$ & $273.20 \pm 1.87^{\mathrm{A}, \mathrm{b}}$ & $457.28 \pm 2.01^{\mathrm{D}, \mathrm{E}}$ & $495.00 \pm 5.64^{\mathrm{A}}$ \\
4 H 51 - 74\% $(\mathrm{n}=115)$ & $294.13 \pm 5.89^{\mathrm{B}}$ & $484.47 \pm 6.34^{\mathrm{B}, \mathrm{F}, \mathrm{c}}$ & $474.00 \pm 17.76^{\mathrm{a}}$ \\
6 R 51-74\% $(\mathrm{n}=459)$ & $286.97 \pm 2.97^{\mathrm{B}}$ & $462.21 \pm 3.19^{\mathrm{d}}$ & $533.40 \pm 8.94^{\mathrm{B}, \mathrm{b}}$ \\
Overall means & 282.27 & 462.94 & 495.00 \\
\hline
\end{tabular}

LSM - least square means; SELSM - standard erorr of least square means; C - Czech Fleckvieh; H - Holstein; R - Red Holstein;

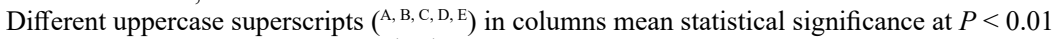

Different lowercase superscripts $(\mathrm{a}, \mathrm{b}, \mathrm{c}, \mathrm{d})$ in columns mean statistical significance at $P<0.05$

The order of lactation was also represented by the lengths of time spent eating and chewing and the number of events of increased activity (Table 2$)$. Feeding time $(+3.64$ to +51.99 min, $P<0.01)$ was longest in heifers but decreased for subsequent lactations. Events of increased activity had a similar trend. Heifers had the most events of increased activity $(519.0 \pm 8.46$ events), which decreased with the progression of lactation to five calvings. Only rumination time had no clear tendencies with the number of lactations. Rumination times during the period around oestrus were longest at the fifth and subsequent lactations, differing only slightly compared to other lactations, but some of these differences were significant.

Table 2. Evaluation for parity effect (LSM \pm SELSM)

\begin{tabular}{|c|c|c|c|}
\hline Lactation order & $\begin{array}{l}\text { Feeding time } \\
(\mathrm{min} / \text { day })\end{array}$ & $\begin{array}{l}\text { Rumination time } \\
(\mathrm{min} / \text { day })\end{array}$ & $\begin{array}{l}\text { Number of incresed activity events } \\
\text { (events/day) }\end{array}$ \\
\hline$(\mathrm{n}=807)$ & $302.24 \pm 2.80^{\mathrm{A}}$ & $461.44 \pm 3.01$ & $519.00 \pm 8.46^{\mathrm{A}}$ \\
\hline$(n=946)$ & $298.60 \pm 2.30^{\mathrm{A}}$ & $469.93 \pm 2.48^{\mathrm{A}}$ & $514.20 \pm 6.90^{\mathrm{A}}$ \\
\hline$(\mathrm{n}=767)$ & $281.60 \pm 2.56^{\mathrm{B}}$ & $465.33 \pm 2.75$ & $479.40 \pm 7.68^{\mathrm{B}}$ \\
\hline$(\mathrm{n}=308)$ & $256.05 \pm 3.47^{\mathrm{C}}$ & $455.57 \pm 3.73^{\mathrm{B}, \mathrm{C}}$ & $467.40 \pm 10.44^{\mathrm{B}}$ \\
\hline 5 and more $(n=452)$ & $250.25 \pm 3.35^{\mathrm{C}}$ & $472.50 \pm 3.60^{\mathrm{D}}$ & $468.00 \pm 10.08^{\mathrm{B}}$ \\
\hline Overall means & 282.27 & 462.94 & 495.00 \\
\hline
\end{tabular}

LSM - least square means; SELSM - standard error of least square means

Different superscripts $(\mathrm{A}, \mathrm{B}, \mathrm{C}, \mathrm{D})$ in columns mean statistical significance at $P<0.01$

The effect of month on the indicators monitored is presented in Table 3. Feeding time during the period around oestrus was longest $(P<0.05-0.01)$ from April to July (289.71-299.45 $\mathrm{min}$ ) and was significantly shorter from October to February. Chewing time during the period around oestrus was longest in November and December and shortest in summer (June to October), but chewing times often differed significantly $(P<0.05-0.01)$. Activity times were similar between months but were longest in January, February, August, and September and often differed significantly between months $(P<0.05-0.01)$.

The effect of days around oestrus at the end of the evaluation is presented in Table 4. Feeding time decreased from 283.55 to 270.93 min between the second day before oestrus and the day after oestrus $(P<0.01)$. Rumination time decreased from the second day before oestrus to the day of oestrus $(-61.80 \mathrm{~min})$ and then increased again $(+33.39 \mathrm{~min})$. Rumination time differed significantly between the days of evaluation $(P<0.01)$. The number of events of increased activity was highest for the day of oestrus $(623 \pm 7.68$ events $)$ and differed significantly between days $(P<0.01)$. 
Table 3. Evaluation for month effect (LSM \pm SELSM).

\begin{tabular}{lcccc}
\hline Month & & $\begin{array}{c}\text { Feeding time } \\
(\mathrm{min} / \text { day })\end{array}$ & $\begin{array}{c}\text { Rumination time } \\
(\mathrm{min} / \text { day })\end{array}$ & $\begin{array}{c}\text { Number of incresed activity events } \\
\text { (events/day) }\end{array}$ \\
\hline January & $(\mathrm{n}=310)$ & $263.98 \pm 3.71^{\mathrm{A}}$ & $472.09 \pm 3.98^{\mathrm{A}}$ & $505.20 \pm 11.16$ \\
February & $(\mathrm{n}=285)$ & $265.84 \pm 3.94^{\mathrm{A}}$ & $456.42 \pm 4.23^{\mathrm{C} . \mathrm{a}}$ & $520.80 \pm 11.82^{\mathrm{A}}$ \\
March & $(\mathrm{n}=390)$ & $273.58 \pm 3.47^{\mathrm{C}}$ & $459.01 \pm 3.73^{\mathrm{E}}$ & $492.60 \pm 10.44$ \\
April & $(\mathrm{n}=360)$ & $299.45 \pm 3.57^{\mathrm{B}, \mathrm{D}, \mathrm{E}}$ & $474.56 \pm 3.84^{\mathrm{G}, \mathrm{b}, \mathrm{c}}$ & $496.80 \pm 10.74$ \\
May & $(\mathrm{n}=305)$ & $297.55 \pm 3.80^{\mathrm{B}, \mathrm{D}, \mathrm{E}, \mathrm{a}}$ & $472.58 \pm 4.09^{\mathrm{I}, \mathrm{e}}$ & $475.20 \pm 11.46$ \\
June & $(\mathrm{n}=270)$ & $298.90 \pm 4.02^{\mathrm{B}, \mathrm{D}, \mathrm{E}, \mathrm{a}}$ & $454.25 \pm 4.33^{\mathrm{H}, \mathrm{K}, \mathrm{f}, \mathrm{g}}$ & $457.80 \pm 12.12^{\mathrm{B}}$ \\
July & $(\mathrm{n}=256)$ & $289.71 \pm 4.11^{\mathrm{B}, \mathrm{G}}$ & $432.52 \pm 4.42^{\mathrm{B}, \mathrm{D}, \mathrm{F}, \mathrm{H}, \mathrm{J}, \mathrm{M}, \mathrm{h}}$ & $497.20 \pm 12.36$ \\
August & $(\mathrm{n}=276)$ & $279.67 \pm 4.00^{\mathrm{F}, \mathrm{b}}$ & $456.09 \pm 4.30^{\mathrm{N}, \mathrm{O}, \mathrm{d}}$ & $507.60 \pm 12.00$ \\
September & $(\mathrm{n}=236)$ & $275.04 \pm 4.22^{\mathrm{F}}$ & $460.62 \pm 4.54^{\mathrm{N}, \mathrm{Q}}$ & $506.40 \pm 12.72$ \\
October & $(\mathrm{n}=220)$ & $261.48 \pm 4.33^{\mathrm{F}, \mathrm{H}}$ & $464.04 \pm 4.66^{\mathrm{N}, \mathrm{S}}$ & $466.80 \pm 13.02$ \\
November & $(\mathrm{n}=211)$ & $261.06 \pm 4.46^{\mathrm{F}, \mathrm{H}}$ & $481.35 \pm 4.80^{\mathrm{D}, \mathrm{F}, \mathrm{L}, \mathrm{N}, \mathrm{P}}$ & $476.40 \pm 13.44$ \\
December & $(\mathrm{n}=231)$ & $267.53 \pm 4.20^{\mathrm{F}, \mathrm{H}}$ & $495.92 \pm 4.52^{\mathrm{B}, \mathrm{D}, \mathrm{F}, \mathrm{L}, \mathrm{N}, \mathrm{P}, \mathrm{R}, \mathrm{T}, \mathrm{d}}$ & $473.40 \pm 12.66$ \\
Overall means & 282.27 & 462.94 & 495.00 \\
\hline
\end{tabular}

LSM - least square means; SELSM - standard erorr of least square means

Different uppercase superscripts (A, B, C, D, E) in columns mean statistical significance at $P<0.01$

Different lowercase superscripts $\left({ }^{\mathrm{a}, \mathrm{b}, \mathrm{c}, \mathrm{d}}\right)$ in columns mean statistical significance at $P<0.05$

Table 4. Evaluation for days around heat effect (LSM \pm SELSM).

\begin{tabular}{lcccc}
\hline Period around oestrus & $\begin{array}{c}\text { Feeding time } \\
(\mathrm{min} / \text { day })\end{array}$ & $\begin{array}{c}\text { Rumination time } \\
(\text { min./day })\end{array}$ & $\begin{array}{c}\text { Number of incresed activity events } \\
(\text { events/day) }\end{array}$ \\
\hline-2 & $(\mathrm{n}=849)$ & $282.25 \pm 2.45^{\mathrm{A}, \mathrm{a}}$ & $490.03 \pm 2.64^{\mathrm{A}}$ & $392.00 \pm 7.38^{\mathrm{A}}$ \\
-1 & $(\mathrm{n}=859)$ & $283.85 \pm 2.45^{\mathrm{A}}$ & $479.94 \pm 2.63^{\mathrm{B}}$ & $423.00 \pm 7.38^{\mathrm{B}}$ \\
0 & $(\mathrm{n}=778)$ & $274.24 \pm 2.54^{\mathrm{B}, \mathrm{b}}$ & $428.23 \pm 2.74^{\mathrm{C}}$ & $623.00 \pm 7.68^{\mathrm{C}}$ \\
1 & $(\mathrm{n}=866)$ & $270.93 \pm 2.45^{\mathrm{B}}$ & $461.62 \pm 2.63^{\mathrm{D}}$ & $521.00 \pm 7.38^{\mathrm{D}}$ \\
\multicolumn{2}{l}{ Overall means } & 282.27 & 462.94 & 495.00 \\
\hline
\end{tabular}

LSM - least square means; SELSM - standard erorr of least square means

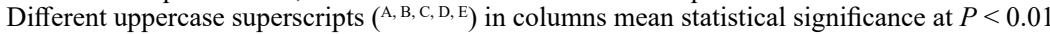

Different lowercase superscripts ( ${ }^{\mathrm{a}, \mathrm{b}, \mathrm{c}, \mathrm{d}}$ ) in columns mean statistical significance at $P<0.05$

\section{Discussion}

Feeding time $(+3.64$ to $+51.99 \mathrm{~min}, \mathrm{P}<0.01)$ was longest in heifers (cows at the first lactation). Gomez and Cook (2010) reported similar results. These studies associated the longer feeding times of heifers with a lower rate of feed intake and more frequent visits to the feeding trough. Heifers receive smaller portions than older dairy cows, when feeding time gradually decreases in subsequent lactations.

Other studies have also found that physical activity was highest for heifers. Similar studies have also concluded that large decreases in rumination time in heifers during oestrus were at the expense of higher activity (Yániz et al. 2006), perhaps due mainly to the higher activity of heifers compared to older dairy cows. This phenomenon (Roelofs et al. 2005) is also explained by the variable length of oestrus, which averages $3 \mathrm{~h}$ longer in heifers than older cows (Yániz et al. 2006) following a 21.4\% decrease in activity in the older cows.

Chewing times in our study were longest at the fifth and subsequent lactations, consistent with the findings of other studies that also reported longer rumination times in older dairy cows (Kowsar et al. 2008). 
Rumination time was longest in winter. Similar results were reported by Acatinai et al. (2010) and Müschner-Siemens et al. (2020), who associated them mainly with heat stress, from which dairy cows do not suffer during winter. In contrast, chewing time for our dairy cows was lowest in summer, consistent with the finding that cows chewed more while standing in the summer than the winter (Acatinai et al. 2010), the same as our results.

The decrease in rumination time in the days before oestrus is associated with a decrease in feed intake, which is strongly correlated with rumination time (Kaske et al. 2002). Indeed, dairy cows spend less time feeding during oestrus. Phillips and Schofield (1990) observed a 5-20\% reduction in feed intake, with the largest decrease on the day of oestrus, because the total intakes of feed and water decrease during oestrus (Reith and Hoy 2012). Feed intake in our experiment had already decreased two days before oestrus. In contrast, Pahl et al. (2015) recorded decreases in feed intake and rumination time only the day before oestrus. Rumination time in dairy cows before oestrus decreases by averages of 18 $20 \%$ (Reith and Hoy 2012). In contrast, the difference between rumination times before and on the day of oestrus in our animals averaged only $12.6 \%$. Pahl et al. (2015) recorded a reduction in rumination time of $68 \mathrm{~min}$ in heifers and of $80 \mathrm{~min}$ in older cows on the day of oestrus, which were slightly higher than in our study, where the average reduction in rumination time was only $61.80 \mathrm{~min}$. Decrease in rumination time, however, may be even smaller during oestrus, as confirmed by Reith and Hoy (2012), who reported an average decrease of only $55 \mathrm{~min}$. Pahl et al. (2015) reported that times returned to normal the day after oestrus.

The activity of dairy cows increases greatly during rutting, in contrast to previous indicators of rumination and feeding times, which decrease during rutting. The activity of dairy cows increases by an average of $38.7 \%$ at the time of oestrus (Firk et al. 2002), when cows are more restless and display more mounting and walking behaviours and when locomotor activity can be four times higher compared to non-ovarian days (Schofield et al. 1991). The amount of time dairy cows spend walking increases linearly from 72 to $16 \mathrm{~h}$ before oestrus and then increases significantly during oestrus (Arney et al. 1994).

The effect of breed on changes in rumination and chewing times and number of events of increased activity during oestrus has not previously been reported. The herd in our study was in a phase of upgrading crossbreeding with Holsteins. Dairy cows with a higher proportion of Holstein blood eat and ruminate longer than do Czech Fleckvieh cows, because milk yield and therefore metabolism are higher.

Vitalimetr 5P was an efficient technology for improving the management of dairy cows. Due to its ability to use more physiological indicators for the detection of oestrus, Vitalimetr $5 \mathrm{P}$ is a good tool for improving the reproductive traits of herds and thus for reducing culling due to the problematic reproduction of dairy cows, thereby increasing profits. Our findings can improve the precision of the algorithm for detecting oestrus in different breeds and in all seasons of the year.

\section{Acknowledgements}

The study was supported from the "S" grant of MŠMT ČR, NAZV project no. QK1910242, CZU SGS project no. SV21-6-21320.

\section{References}

Acatinai S, Gavojdian D, Stanciu G, Toma Cziszter L, Tripon I, Baul S 2010: Study regarding rumination behavior in cattle-position adopted by cows during rumination process. Anim Sci Biotechnol 43: 2

Arney DR, Kitwood SE, Phillips CJC 1994: The increase in activity during oestrus in dairy cows. Appl Anim Behav Sci 40: 211-218

At-Taras EE, Spahr SL 2001: Detection and characterization of estrus in dairy cattle with an electronic heatmount detector and an electronic activity tag. J Dairy Sci 84: 792-798 
Brehme U, Stollberg U, Holz R, Schleusener T 2008: ALT pedometer-New sensor-aided measurement system for improvement in oestrus detection. Comput Electron Agric 62: 73-80

De Vries A 2006: Economic value of pregnancy in dairy cattle. J Dairy Sci 89: $3876-3885$

Diskin MG, Sreenan JM 2000: Expression and detection of oestrus in cattle. Reprod Nutr Dev 40: 481-491

Firk R, Stamer E, Junge W, Krieter J 2002: Automation of oestrus detection in dairy cows: A review. Livest Prod Sci 75: 219-232

Gomez A, Cook NB 2010: Time budgets of lactating dairy cattle in commercial freestall herds. J Dairy Sci 93: $5772-5781$

Kaske M, Beyerbach M, Hailu Y, Göbel W, Wagner S 2002: The assessment of the frequency of chews during rumination enables an estimation of rumination activity in hay-fed sheep. J Anim Physiol Anim Nutr (Berl) 86: $83-89$

Kowsar R, Ghorbani GR, Alikhani M, Khorvash M, Nikkhah A 2008: Corn silage partially replacing short alfalfa hay to optimize forage use in total mixed rations for lactating cows. J Dairy Sci 91: 4755-4764

Løvendahl P, Chagunda MGG 2010: On the use of physical activity monitoring for estrus detection in dairy cows. J Dairy Sci 93: 249-259

Müschner-Siemens T, Hoffmann G, Ammon C, Amon T 2020: Daily rumination time of lactating dairy cows under heat stress conditions. J Therm Biol 88: 102484

Pahl C, Hartung E, Mahlkow-Nerge K, Haeussermann A 2015: Feeding characteristics and rumination time of dairy cows around estrus. J Dairy Sci 98: 148-154

Phillips CJC, Schofield SA 1990: The effect of environment and stage of the oestrous cycle on the behaviour of dairy cows. Appl Anim Behav Sci 27: 21-31

Reith S, Hoy S 2012: Relationship between daily rumination time and estrus of dairy cows. J Dairy Sci $\mathbf{9 5}$ : 6416-6420

Reith S, Brandt H, Hoy S 2014: Simultaneous analysis of activity and rumination time, based on collar-mounted sensor technology, of dairy cows over the peri-estrus period. Livest Sci 170: 219-227

Roelofs JB, Van Eerdenburg FJCM, Soede NM, Kemp B 2005: Pedometer readings for estrous detection and as predictor for time of ovulation in dairy cattle. Theriogenology 64: 1690-1703

Schofield SA, Phillips CJC, Owens AR 1991: Variation in the milk production, activity rate and electrical impedance of cervical mucus over the oestrous period of dairy cows. Anim Reprod Sci 24: 231-248

Yániz JL, Santolaria P, Giribet A, López-Gatius F 2006: Factors affecting walking activity at estrus during postpartum period and subsequent fertility in dairy cows. Theriogenology 66: 1943-1950 